\title{
Analitycal Hierarchy Process Untuk Menganalisa Faktor Pemilihan Web Browser Pada Desktop
}

\author{
Wida Prima Mustika ${ }^{1}$, Mardian ${ }^{2}$, Rinawati ${ }^{3}$ \\ 1,2,3Sekolah Tinggi Manajemen Informatika dan Komputer Nusa Mandiri \\ (STMIK Nusa Mandiri) \\ Jl. Kramat Raya No.18 Jakarta Pusat \\ wida.wpm@nusamandiri.ac.id, iancassanova.ic@gmail.com, rinawati.riw@nusamandiri.ac.id
}

\begin{abstract}
Convenience in using the internet is strongly influenced by the web browser used. Web browser is an application to be able to surf the internet, which serves to display and interact with the server. The development of the internet and the increasing number of website are there, make the internet as the primary source of information. With options and advantages possessed by each web browser, internet users often do not make the most of the features provided. It is that makes the background of how to apply the research methods Analytical Hierarchy Process (AHP) for choosing a web browser on the desktop. This research aims to create a decision support system for internet users in selecting the appropriate web browser criteria and requirements.
\end{abstract}

Keywords : Web Browser, Internet, Analytical Hierarchy Process (AHP), DSS

\begin{abstract}
Abstrak
Kenyamanan dalam menggunakan internet sangat dipengaruhi oleh web browser yang digunakan. Web browser merupakan aplikasi untuk dapat menjelajah internet, yang berfungsi menampilkan dan melakukan interaksi dengan server. Berkembangnya internet dan semakin banyaknya website yang ada, menjadikan internet sebagai sumber informasi yang utama. Dengan banyaknya pilihan dan kelebihan yang dimiliki oleh masing-masing web browser, para pengguna internet sering tidak memanfaatkan secara maksimal fitur yang disediakan. Hal ini yang menjadikan latar belakang penelitian bagaimana menerapkan metode Analytical Hierarchy Process (AHP) untuk memilih web browser pada desktop. Penelitian ini bertujuan untuk membuat sistem penunjang keputusan bagi pengguna internet dalam memilih web browseryang tepat sesuai kriteria dan kebutuhan.
\end{abstract}

Kata kunci : Web browser, internet, Analytical Hierarchy Process, SPK

\section{PENDAHULUAN}

Web browser merupakan perangkat lunak yang fungsinya menerima dan menyajikan informasi di internet. Sumber informasi bisa dilihat menggunakan web browser, baik yang berupa halaman web, gambar, video, atau jenis konten lainnya[1]. Dewasa ini browser begitu maju dan berkembang pesat, namun tidak semua pengguna memanfaatkan fitur-fitur yang sudah disediakan oleh browser. Hal ini sangat disayangkan, karena pengguna tidak sepenuhnya tahu akan manfaat dari sebuah browser yang sangat membantu dalam menelusuri internet menjadi lebih mudah dan efektif. Terkadang pengguna hanya memilih browser dari tingkat 
kepopulerannya saja atau mengikuti trend yang ada pada saat itu tanpa mengetahui dengan baik keunggulan dari sebuah browser tersebut.

Penelitian terdahulu mengenai pemilihan web browser seperti penelitian yang dilakukan oleh retnoningsing yang menerapkan metode Analityc Hierarchy Process (AHP) untuk memilih desktop web browser, penelitian ini mempunyai tujuan untuk membuat sistem penunjang keputusan bagi pengguna internet dalam menentukan pilihan desktop web browser yang tepat sesuai kriteria dan kebutuhan [2].

\section{METODOLOGI PENELITIAN}

Teknik terakhir yang akan dibahas dalam situasi pengambilan keputusan adalah teknik Analytical Hierarchy Process (AHP). Teknik ini dikembangkan oleh L.Saaty tahun 1970. Teknik Analytical Hierarchy Process (AHP) membantu pengambilan keputusan memilih sebuah alternatif yang memberikan hasil paling mendekati tujuannya. Teknik ini sudah dilakukan oleh para pengambil keptusan sejak lama, yaitu dalam fikiran mereka, tetapi AHP memvisualkan apa yang mereka fikirkan dan rasakan sehingga pemahaman terhadap situasi keputusan menjadi semakin baik [3].

Kelebihan AHP diantaranya adalah [4][5] :

1. Struktur yang berhirarki, sebagai konsekuensi dari kriteria yang dipilih, sampai pada subkriteria yang paling dalam.

2. Memperhitungkan validitas sampai dengan batas toleransi inkonsistensi berbagai kriteria dan alternative yang dipilih oleh para pengambil keputusan.

3. Memperhitungkan daya tahan atau tahanan output analisis sensitivitas pengambilan keputusan.

Expert Choice merupakan salah satu software AHP yang memiliki kelebihan dibanding criterium decision plus. Kelebihan software Expert Choice adalah memiliki tampilan antarmuka yang lebih menarik, mampu untuk mengintegrasikan pendapatan pakar, tidak membatasi level dari struktur hirarki [6].

Browser memiliki istilah lain yaitu web browser, peramban serta penjelajah web. Secara umum, browser adalah suatu aplikasi atau program yang dijalankan pada perangkat komputer untuk menjelajah konten atau isi yang ada pada media World Wide Web (WWW) dengan memanfaatkan jaringan internet. Teknologi browser yang berkembang saat ini tidak hanya bisa menampilkan halaman yang berisi teks atau tulisan saja, browser sekarang juga bisa menampilkan konten gambar, musik, suara, video, file pdf dan data lainnya [7].

Ada beberapa jenis Browser yang sedang popular saat ini, yaitu [7] :

\section{Microsoft Internet Explorer}

Internet Explorer atau disingkat IE merupakan merk dagang yang dipelopori oleh perusahaan terkemuka yaitu Microsoft Corp. Internet Explorer bias dikatakan merupakan salah satu browser paling tua, 
pengguna computer pada zaman dahulu pasti sudah tidak asing lagi dengan browser ini.

\section{Google Chrome}

Google Chrome dibentuk dan dikembangakan oleh sang raksasa mesin pencari Google. Browser ini dirilis pada 2 September 2008, dan pada saat itu hanya digunakan untuk Microsoft Windows karena masih dalam status beta. Google chrome menjadi browser terpopuler karena banyaknya fitur yang tersedia didalamnya dan kecepatan respon yang dimilikinya.

\section{Mozilla Firefox}

Versi pertama Mozilla Firefox dirilis pada tanggal 9 November 2004 oleh Yayasan Mozilla dan langsung disambut baik oleh masyarakat. Terhitung pada bulan September 2014 penggunaan browser ini sudah mencapai 12\% sampai $22 \%$, bahkan di Indonesia sendiri browser ini sudah mencapai $55 \%$ dari total pengguna internet.

\subsection{Desain Penelitian}

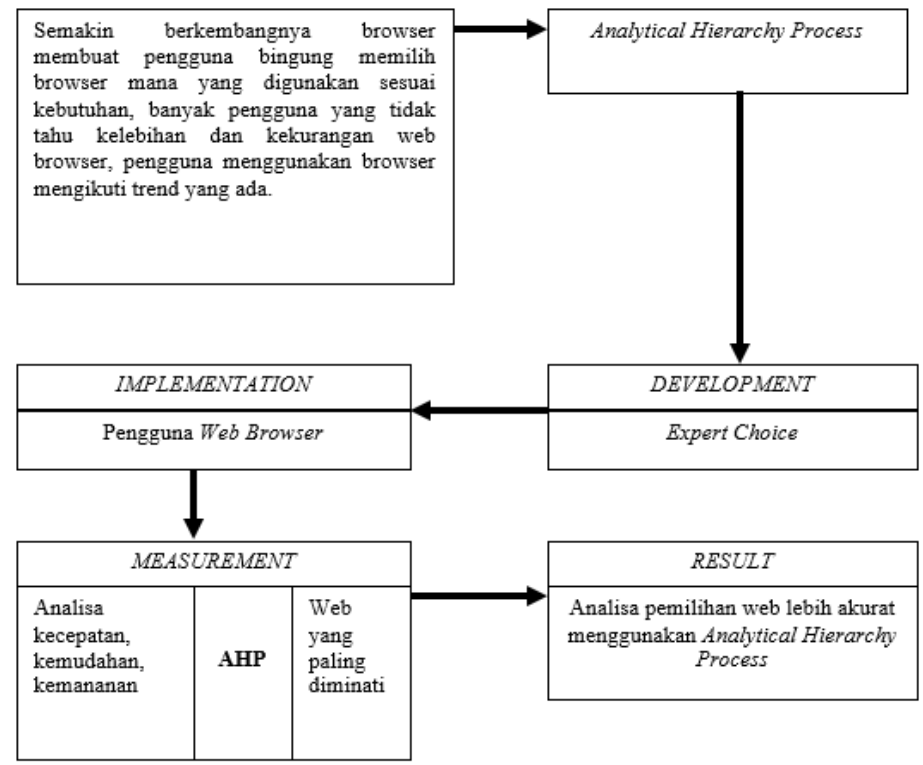

\subsection{Pengumpulan Data}

Gambar 1. Desain Penelitian

Proses pengumpulan data pada analisa faktor pemilihan Web Browser pada Desktop ini meliputi penentuan tujuan penelitian, kriteria dan alternatif objek penelitian. Data primer diperoleh dengan cara data survei kuesioner dari responden, data kriteria, dan data alternatif browser. Data sekunder penunjang diperoleh dari beberapa sumber referensi pustaka penelitian sebelumnya untuk melengkapi laporan penelitian.

1. Angket Kuesioner

Merupakan pengumpulan data dengan lembar kuesioner yang diberikan kepada responden untuk memperoleh data nilai pembobotan sebagai perhitungan penerapan metode AHP dalam analisa faktor pemilihan web browser pada desktop. 
2. Studi Pustaka

Merupakan metode pengumpulan data melalui buku, jurnal, internet dan literature lain yang masih berkaitan dengan pembahasan dan penunjang penelitian.

\subsection{Pengolahan Data}

Pada penelitian untuk menganalisa faktor pemilihan web browser pada desktop dengan metode Analytical Hierarchy Process (AHP) ini, peneliti mengambil sampel dari beberapa pengguna web browser. Dan para pengguna web diambil dari beberapa kalangan diantaranya:

1. Kalangan pelajar disekitar lingkungan Sekolah Menengah Kejuruan Teratai Putih Global Bekasi (kranji).

2. Kalangan mahasiswa disekitar lingkungan kampus STMIK Nusamandiri.

3. Kalangan mahasiswa disekitar lingkungan Universitas Assyafiiyah Jatiwaringin.

4. Kalangan pekerja disekitar lingkungan Apotek K24 Bekasi Jatimulya.

\section{HASIL DAN PEMBAHASAN}

\subsection{Analisa Penerapan Analitycal Hierarchy Process (AHP)}

Penentuan skala prioritas dengan menggunakan metode Analytical Hierarchy Process (AHP) dari web browser sendiri bertujuan untuk menganalisa web browser yang paling sering dipilih atau yang paling sering digunakan oleh pengguna web dari beberapa kriteria yang telah dipilih oleh peneliti. Adapun kriteria yang telah dipilih oleh peneliti adalah kriteria kecepatan, keamanan, kemudahan pada alternatif web browser seperti Google Chrome, Mozilla firefox, Internet Explorer. Hasil rekapitulasi data kuesioner yang sudah ada akan divalidasi dan selanjutnya data akan dianalisa dengan menggunakan prinsip dasar metode Analytical Hierarchy Process (AHP).

\section{a. Struktur Hirarki Model}

Struktur atau diagram hirarki model dibuat berdasarkan tujuan, kriteria dan alternatif dari penelitian yang sudah ada disesuaikan dengan kalsifikasi level keputusan dalam metode Analytical Hierarchy Process (AHP). Dalam kasus analisa faktor pemilihan web browser pada desktop ini, hubungan antara kriteria dan alternatif ini dapat digambarkan sebagai berikut.

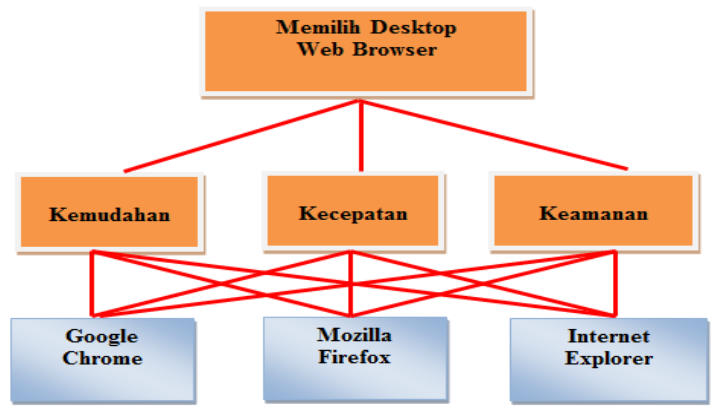

Gambar 2. Hirarki Pemilihan Desktop Web Browser 


\section{b. Penyebaran Kuesioner Pada Responden}

Data-data yang telah diperoleh dari responden dengan menggunakan angket kuesioner, selanjutnya akan dilakukan rekapitulasi berdasarkan kriteria yang telah ditetapkan dari setiap alternatif pemilihan desktop web browser. Kuesioner yang disebarkan sebanyak 50 eksemplar untuk 50 orang responden pengguna web browser.

\section{c. Perhitungan Hasil Kuesioner}

Pengolahan data kuesioner dimulai dari data hasil kuesioner, kemudian dilanjutkan dengan perhitungan dengan menggunakan prosedur Analytic Hierarchy Process (AHP).

Jawaban responden dinilai konsisten apabila nilai Cosistency Ratio (CR) nya kurang dari $0.10(<0.10)$. Kuesioner yang memiliki nilai kurang dari 0.10 inilah yang digunakan dalam analisa selanjutnya. Sebaliknya, jawaban responden dinilai tidak konsisten apabila nilai Consistency Ratio (CR) nya lebih besar dari 0.10. Kuesioner yang memiliki nilai lebih dari 0.10 ini dianggap gugur dan tidak dapat digunakan untuk analisa selanjutnya. Pada Tabel dibawah ini dapat dilihat matrik jawaban responden 1 yang akan dilakukan pengujian konsistensi.

Tabel 1. Matrik Jawaban Responden

\begin{tabular}{|c|c|c|c|}
\hline Kriteria & Kecepatan & Keamanan & Kemudahan \\
\hline Kecepatan & 1.0000 & 0.3333 & 0.3333 \\
\hline Keamanan & 3.0000 & 1.0000 & 2.0000 \\
\hline Kemudahan & 3.0000 & 0.5000 & 1.0000 \\
\hline Jumlah & 7.0000 & 1.8333 & 3.3333 \\
\hline
\end{tabular}

Dengan melakukan penilaian relatif pada setiap sel, yaitu dengan cara membagi nilai setiap sel dengan jumlah pada setiap kolomnya maka akan diperoleh nilai relatif per sel. Selanjutnya pada faktor horizontal dijumlahkan dan dicari prioritasnya. Hasilnya dapat dilihat pada tabel berikut.

Tabel 2. Nilai Prioritas Untuk Responden 1

\begin{tabular}{|c|c|c|c|c|c|}
\hline Kriteria & KC & KA & KM & Jumlah & Prioritas \\
\hline KC & 0.142 & 0.181 & 0.100 & 0.424 & 0.141 \\
\hline KA & 0.428 & 0.545 & 0.600 & 1.574 & 0.524 \\
\hline KM & 0.428 & 0.272 & 0.300 & 1.001 & 0.333 \\
\hline Jumlah & 1.000 & 1.000 & 1.000 & 3.000 & 1.000 \\
\hline
\end{tabular}

Keterangan : KC : Kecepatan, KA : Keamanan, KM : Kemudahan

Setelah didapat nilai seperti diatas maka selanjutnya dilakukan pengujian konsistensi. Cara menguji konsistensi setiap matriks berpasangan kriteria adalah sebagai berikut: 
$\lambda$ maks $=\left(\left(7^{*} 0.1415\right)+\left(1.8^{*} 0.5246\right)+\left(3.3^{*} 0.3337\right)=3.0653\right.$

$\mathrm{CI}=\frac{(\lambda \text { maks }-\mathrm{n})}{(\mathrm{n}-1)} \quad \frac{(3.06053-3)}{(3-1)}=0.0326$

$\mathrm{CR}=\frac{\mathrm{CI}}{\mathrm{IR}} \quad \frac{=0.0326}{0.58} \quad=0.0563$

Jadi, perhitungan ini konsisten karena Consistency Ratio atau CR $\leq 0.1$.

Berdasarkan hasil verifikasi data diatas, dapat dinyatakan bahwa responden 1 dinilai konsisten karena Consistency Ratio (CR) nya kurang dari 0.10 $(<0.10)$. Maka jawaban responden dinyatakan konsisten dan dapat dilakukan perhitungan selanjutnya. Dari hasil kuesioner yang sudah dihitung yaitu, 50 eksemplar kuesioner, terdapat 32 responden yang menjawab konsisten dan sisanya menjawab tidak konsisten atau gugur. Berikut ini adalah tabel data kuesioner responden yang telah dihitung.

Tabel 3. Hasil Pengujian Seluruh Kuesioner

\begin{tabular}{|c|c|c|c|c|}
\hline No. & RESPONDEN & CI & CR & KETERANGAN \\
\hline 1 & R1 & 0.0326 & 0.0563 & Konsisten \\
\hline 2 & R2 & 0.0268 & 0.0463 & Konsisten \\
\hline 3 & R3 & 0.0268 & 0.0463 & Konsisten \\
\hline & R4 & 0.3161 & 0.5451 & Tidak Konsisten \\
\hline 5 & R5 & 0.0268 & 0.0463 & Konsisten \\
\hline & R6 & 0.2839 & 0.4895 & Tidak Konsisten \\
\hline 7 & R7 & 0.0473 & 0.0816 & Konsisten \\
\hline 8 & R8 & 0.0268 & 0.0462 & Konsisten \\
\hline 9 & R9 & 2.415 & 4.1639 & Tidak Konsisten \\
\hline 10 & R10 & 0.4454 & 0.768 & Tidak Konsisten \\
\hline 11 & R11 & 0.0091 & 0.0157 & Konsisten \\
\hline 12 & R12 & 0.1498 & 0.2583 & Tidak Konsisten \\
\hline 13 & R13 & 0.0268 & 0.0463 & Konsisten \\
\hline 14 & R14 & 0.0268 & 0.0463 & Konsisten \\
\hline 15 & R15 & 0.0046 & 0.0079 & Konsisten \\
\hline 16 & R16 & 0.0268 & 0.0462 & Konsisten \\
\hline 17 & R17 & 0.1852 & 0.3194 & Tidak Konsisten \\
\hline 18 & R18 & 0.3217 & 0.5547 & Tidak Konsisten \\
\hline 19 & R19 & 0.1302 & 0.2246 & Tidak Konsisten \\
\hline 20 & R20 & 0.0269 & 0.0464 & Konsisten \\
\hline 21 & R21 & 0.1852 & 0.3194 & Tidak Konsisten \\
\hline 22 & R22 & 0.0475 & 0.082 & Konsisten \\
\hline 23 & R23 & 0.0268 & 0.0463 & Konsisten \\
\hline 24 & R24 & 0.0091 & 0.0157 & Konsisten \\
\hline 25 & R25 & 0.3641 & 0.6277 & Tidak Konsisten \\
\hline 26 & R26 & 0.0027 & 0.0047 & Konsisten \\
\hline 27 & R27 & 0.0013 & 0.0022 & Konsisten \\
\hline 28 & R28 & 0.25 & 0.431 & Tidak Konsisten \\
\hline 29 & R29 & 0.0018 & 0.0031 & Konsisten \\
\hline 30 & R3o & 0.0475 & 0.0819 & Konsisten \\
\hline 31 & R31 & 0.2839 & 0.4895 & Tidak Konsisten \\
\hline 32 & R32 & 0.1848 & 0.3187 & Tidak Konsisten \\
\hline 33 & R33 & 0.0268 & 0.0462 & Konsisten \\
\hline 34 & R34 & 0.0272 & 0.047 & Konsisten \\
\hline 35 & R35 & 0.0091 & 0.0158 & Konsisten \\
\hline 36 & R36 & 0.9277 & 1.5995 & Tidak Konsisten \\
\hline 37 & R37 & 0.0477 & 0.0823 & Konsisten \\
\hline 38 & R38 & 0.0091 & 0.0157 & Konsisten \\
\hline 39 & R39 & 0.0175 & 0.0303 & Konsisten \\
\hline 40 & R40 & 0.0433 & 0.0747 & Konsisten \\
\hline 41 & R41 & 1.2293 & 2.1195 & Tidak Konsisten \\
\hline 42 & R42 & 0.0268 & 0.0463 & Konsisten \\
\hline 43 & R43 & 0.0268 & 0.0462 & Konsisten \\
\hline 44 & R44 & 0.0288 & 0.0496 & Konsisten \\
\hline 45 & R45 & 1.7127 & 2.9529 & Tidak Konsisten \\
\hline 46 & R46 & 0.0269 & 0.0464 & Konsisten \\
\hline 47 & R47 & 0.0542 & 0.0934 & Konsisten \\
\hline 48 & R48 & 0.068 & 0.1173 & Tidak Konsisten \\
\hline 49 & R49 & 0.0175 & 0.0302 & Konsisten \\
\hline 2 & R50 & 0.069 & 0.119 & Tidak Kc \\
\hline
\end{tabular}




\section{d. Pembobotan Kriteria}

Tabel 4. Matriks Berpasangan Kriteria

\begin{tabular}{|l|r|r|r|}
\hline KRITERIA & KECEPATAN & KEAMANAN & KEMUDAHAN \\
\hline KECEPATAN & 1 & 2 & 2 \\
\hline KEAMANAN & 0.5 & 1 & 2 \\
\hline KEMUDAHAN & 0.5 & 0.5 & 1 \\
\hline JUMLAH & $\mathbf{2}$ & $\mathbf{3 . 5}$ & $\mathbf{5}$ \\
\hline
\end{tabular}

Matriks perbandingan berpasangan diisi menggunakan bilangan untuk mempresentasikan kepentingan relatif dari suatu elemen terhadap elemen lainnya. Nilai elemen kolom yang dinilai didapat dari hasil bagi dengan nilai kriteria yang dinilai. Jika suatu kriteria dalam baris bertemu dengan kriteria yang sama dalam kolom maka nilai elemen tersebut adalah 1. Contohnya hasil 0.5 di kolom kriteria kecepatan, baris kriteria keamanan didapat dari 1 dibagi 2. Nilai 1 di kolom kriteria kecepatan, baris kriteria kecepatan. Nilai 2 di kolom kriteria keamanan, baris kriteria kecepatan.

Tabel 5. Normalisasi Matriks Antar Kriteria

\begin{tabular}{|l|r|r|r|r|r|}
\hline KRITERIA & KECEPATAN & KEAMANAN & KEMUDAHAN & JUMLAH & PRIORITAS \\
\hline KECEPATAN & 0.5 & 0.571428571 & 0.4 & 1.471428571 & 0.49047619 \\
\hline KEAMANAN & 0.25 & 0.285714286 & 0.4 & 0.935714286 & 0.311904762 \\
\hline KEMUDAHAN & 0.25 & 0.142857143 & 0.2 & 0.592857143 & 0.197619048 \\
\hline JUMLAH & 1 & 1 & 1 & & \\
\hline
\end{tabular}

Menghitung normalisasi matriks dengan rumus masing-masing elemen kolom dibagi dengan dengan jumlah matriks kolom. Lalu jumlahkan setiap baris dan kolom. Nilai eigen vector atau prioritas didapat dari jumlah baris normalisasi dibagi dengan jumlah kriteria. Berikut ini adalah cara perhitungan pengujian konsistensi setiap matriks berpasangan kriteria adalah sebagai berikut:

$\lambda$ maks $=\left((2 * 0.4904)+\left(3.5^{*} 0.3119\right)+\left(5^{*} 0.1976\right)=3.06045\right.$

$$
\begin{aligned}
& \mathrm{CI}=\left(\lambda \frac{\text { maks }-\mathrm{n})}{(\mathrm{n}-1)}=\frac{(3.06045-3)}{(3-1)}=0.030225\right. \\
& \mathrm{CR} \frac{\mathrm{CI}}{\mathrm{IR}} \quad \frac{=0.030225}{0.58}=0.052112
\end{aligned}
$$

Jadi, perhitungan ini konsisten karena Consistency Ratio atau CR $\leq 0.1$.

\section{e. Pembobotan Alternatif}

Rata-rata dari hasil pengolahan kuesioner terhadap penilaian kriteria yang didapat, selanjutnya dibuat pembobotan untuk menilai perbandingan antar kriteria dan alternative dari beberapa objek yang sudah di teliti. 
Tabel 6. Matriks Berpasangan Alternatif Kemudahan

\begin{tabular}{|l|r|r|r|}
\hline KRITERIA & \multicolumn{1}{|c|}{ MOZILLA } & \multicolumn{1}{|c|}{ EXPLORER } & \multicolumn{1}{l|}{ CHROME } \\
\hline MOZILLA & 1 & 3 & 2 \\
\hline EXPLORER & 0.33333333 & 1 & 1 \\
\hline CHROME & 0.5 & 1 & 1 \\
\hline JUMLAH & $\mathbf{1 . 8 3 3 3 3 3 3 3}$ & $\mathbf{5}$ & $\mathbf{4}$ \\
\hline
\end{tabular}

Tabel 7. Matriks Berpasangan Alternatif Kecepatan

\begin{tabular}{|l|r|r|r|}
\hline KRITERIA & MOZILLA & \multicolumn{1}{|c|}{ EXPLORER } & \multicolumn{1}{|c|}{ CHROME } \\
\hline MOZILLA & 1 & 2 & 1 \\
\hline EXPLORER & 0.5 & 1 & 1 \\
\hline CHROME & 1 & 1 & 1 \\
\hline JUMLAH & 2.5 & 4 & 3 \\
\hline
\end{tabular}

Tabel 8. Matriks Berpasangan Alternatif Keamanan

\begin{tabular}{|l|r|r|r|}
\hline KRITERIA & MOZILLA & EXPLORER & \multicolumn{1}{|c|}{ CHROME } \\
\hline MOZILLA & 1 & 2 & 1 \\
\hline EXPLORER & 0.5 & 1 & 1 \\
\hline CHROME & 1 & 1 & 1 \\
\hline JUMLAH & 2.5 & 4 & 3 \\
\hline
\end{tabular}

\section{f. Perhitungan Prioritas Global}

Untuk mendapatkan bobot prioritas menyeluruh dari tiap-tiap alternatif, maka harus dilakuakan perkalian antar bobot prioritas global dengan bobot prioritas local alternatif dari masing masing kelompok kriteria. Pada tabel dibawah ini dapat dilihat perkalian antara bobot prioritas global dengan bobot prioritas lokal alternatif.

Tabel 9. Bobot Prioritas Lokal Alternatif dan Bobot Global

\begin{tabular}{|l|r|r|r|}
\hline \multirow{2}{*}{ ALTERNATIF } & \multicolumn{3}{|c|}{ KRITERIA } \\
\cline { 2 - 4 } & KECEPATAN & KEAMANAN & KEMUDAHAN \\
\cline { 2 - 4 } & 0.4904 & 0.3119 & 0.1976 \\
\hline MOZILLA & 0.4111 & 0.4111 & 0.5484 \\
\hline EXPLORER & 0.2611 & 0.2611 & 0.2106 \\
\hline CHROME & 0.3277 & 0.3277 & 0.2409 \\
\hline
\end{tabular}

Tabel 10. Bobot Prioritas Global

\begin{tabular}{|l|r|r|r|r|}
\hline KRITERIA & KECEPATAN & KEAMANAN & KEMUDAHAN & PRIORITAS \\
\hline MOZILLA & 0.4111 & 0.4111 & 0.5484 & 0.4569124 \\
\hline EXPLORER & 0.2611 & 0.2611 & 0.2106 & 0.2442911 \\
\hline CHROME & 0.3277 & 0.3277 & 0.2409 & 0.2987965 \\
\hline JUMLAH & 1 & 1 & 1 & 1 \\
\hline
\end{tabular}


Dari prioritas global pada tabel diatas dapat dinyatakan bahwa alternatif web browser Mozilla Firefox memiliki bobot prioritas global tertinggi yaitu sebesar 0.4569 atau sekitar 45.69\%, yang kedua adalah Google Chrome memiliki bobot prioritas global sebesar 0.2987 atau sekitar 29.87\%, sedangkan Internet Explorer menempati urutan ketiga, yaitu memiliki bobot prioritas global sebesar 0.2442 atau sekitar $24.42 \%$.

\subsection{Implementasi Expert Choice}

AHP dapat dikerjakan dengan menggunakan bantuan software Expert Choice. Expert Choice merupakan salah satu software yang secara luas digunakan dalam menganalisis pembobotan Analytic Hierarchy Process (AHP).

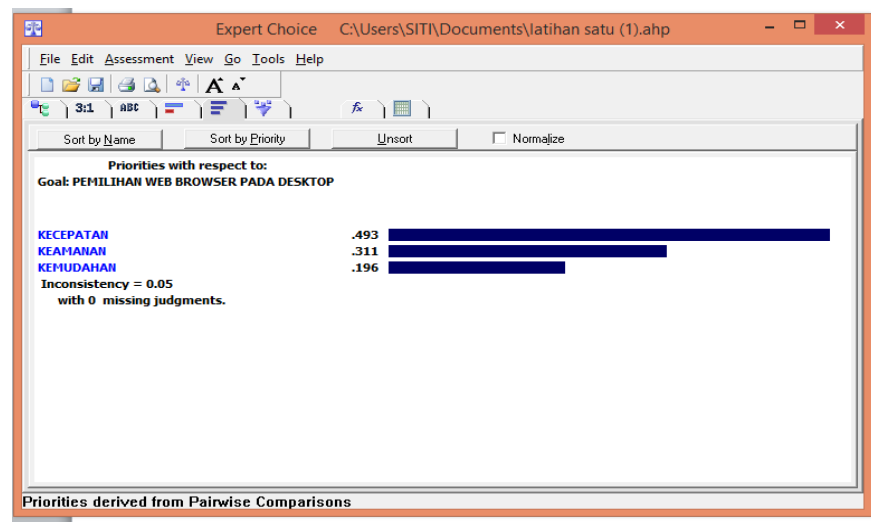

Gambar 3. Hasil Sintesis Antar Kriteria

Dari gambar 3 diatas dapat disimpulkan bahwa kriteria kecepatan paling berpengaruh dan paling dipertimbangkan dalam pemilihan web browser, karena memiliki bobot prioritas yang paling tinggi, yaitu sebesar 0.493 atau sekitar 49.3\%, kedua adalah kriteria keamanan dengan bobot prioritas 0.311 atau sekitar $31.1 \%$ dan yang terakhir adalah kemudahan, yaitu dengan bobot prioritas 0.196 atau sekitar $19.6 \%$.

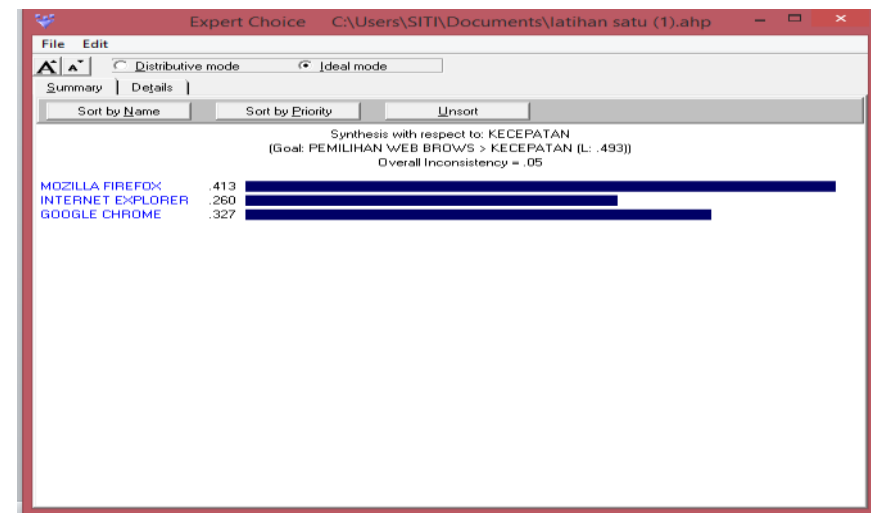

Gambar 4. Hasil Sintesis Kriteria Kecepatan

Dari gambar 4 diatas dapat disimpulkan bahwa bobot prioritas kecepatan pada Mozilla Firefox lebih tinggi, yaitu dengan nilai sebesar 0.413 atau sekitar 41.3\%. Yang kedua adalah bobot prioritas kecepatan pada Google Chrome, yaitu dengan nilai sebesar 0.327 atau sekitar 32.7\%. Dan yang terakhir 
adalah bobot prioritas kecepatan pada Internet Explorer, yaitu dengan nilai sebesar 0.260 atau sekitar $26.0 \%$.

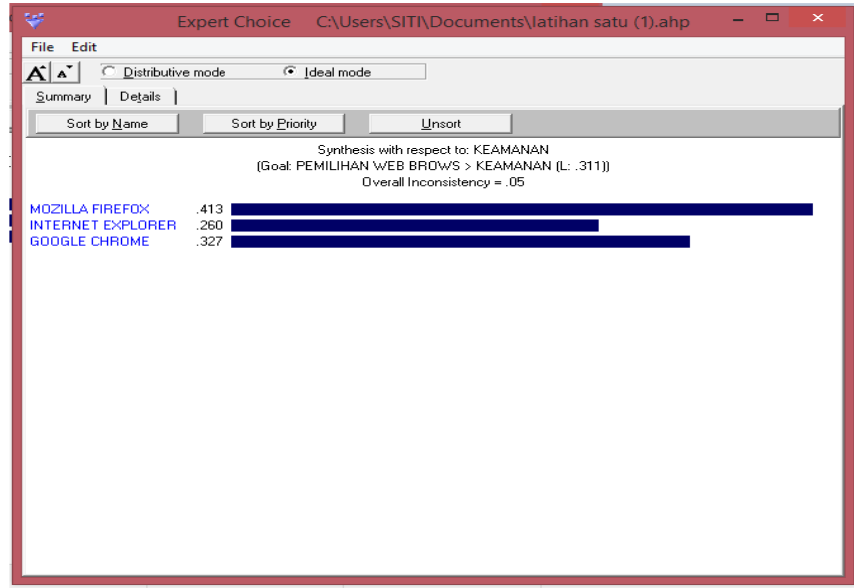

Gambar 5. Hasil Sintesis Kriteria Keamanan

Dari gambar 5 diatas dapat disimpulkan bahwa bobot prioritas keamanan pada Mozilla Firefox lebih tinggi, yaitu dengan nilai sebesar 0.413 atau sekitar 41.3\%. Yang kedua adalah bobot prioritas keamnan pada Google Chrome, yaitu dengan nilai sebesar 0.327 atau sekitar 32.7\%. Dan yang terakhir adalah bobot prioritas keamanan pada Internet Explorer, yaitu dengan nilai sebesar 0.260 atau sekitar $26.0 \%$.

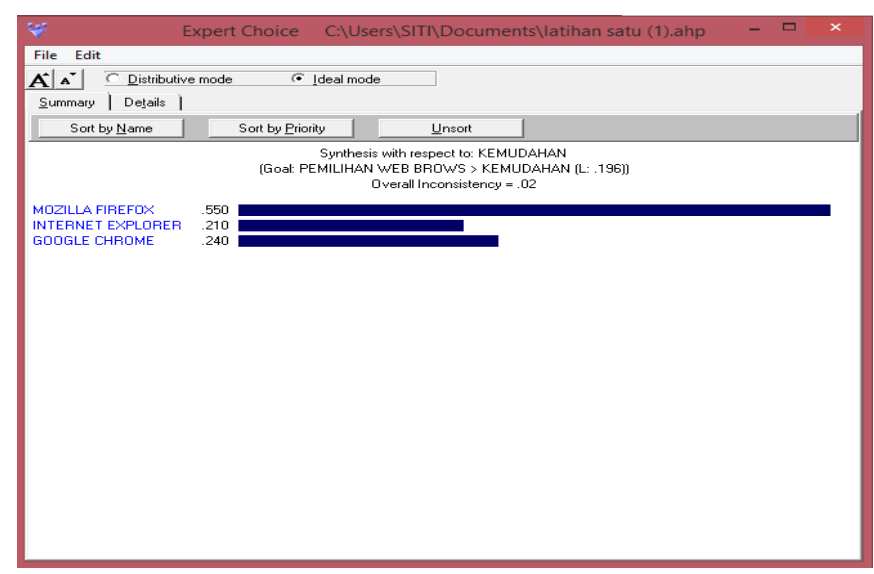

Gambar 6. Hasil Sintesis Kriteria Kemudahan

Dari gambar 6. diatas dapat disimpulkan bahwa bobot prioritas kemudahan pada Mozilla Firefox lebih tinggi, yaitu dengan nilai sebesar 0.550 atau sekitar 55.0\%. Yang kedua adalah bobot prioritas kecepatan pada Google Chrome, yaitu dengan nilai sebesar 0.240 atau sekitar $24.0 \%$. Dan yang terakhir adalah bobot prioritas kecepatan pada Internet Explorer, yaitu dengan nilai sebesar 0.210 atau sekitar $21.0 \%$. 


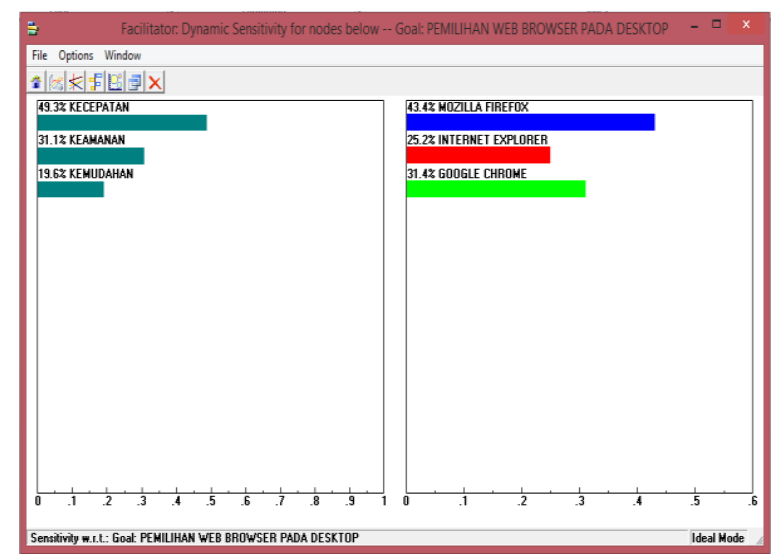

Gambar 7. Sensitivity Graph Dynamic

Gambar Sensitivity Graph Dynamic diatas merupakan grafik yang menampilkan hubungan masing-masing alternatif dan kriteria. Diagram ini menunjukan bahwa kecepatan paling berperan penting dalam menentukan pemilihan web browser yang akan digunakan, yaitu sebanyak 49.3\%. Sedangkan Mozilla Firefox adalah web yang paling diminati oleh para pengguna web browser, yaitu sebesar 43.4\%.

\section{KESIMPULAN}

Sistem Penunjang Keputusan dengan metode AHP dapat digunakan dalam pengambilan keputusan dalam analisa pemilihan web browser dengan memberikan kriteria dan alternatif. Desktop web browser yang lebih unggul pada penelitian ini dalam hal kecepatan adalah Mozilla firefox yang paling banyak dipilih pengguna saat berinternet dengan bobot prioritas global tertinggi yaitu sebesar 0.4569 atau sekitar $45.69 \%$.Keamanan Tetap menjadi faktor prioritas bagi para pengguna web browser dalam melakukan aktifitas berinternet dengan bobot prioritas 0.3119 atau sekitar $31.19 \%$.

\section{DAFTAR PUSTAKA}

[1] Winarno, Edy, Ali Zaki, Dan smitDev Community. [2014]. Panduan Lengkap Berinternet

[2] Retnoningsing, Endang. [2014]. Sistem Pendukung Keputusan Pemilihan Desktop Web Browser.

[3] Triono, Rachmadi Agus. [2017]. Pengambilan Keputusan Manajerial Teori dan Praktik Untuk Manajer dan Akademisi.

[4] Suryadi, Kadarsah, dan M. Ali Ramadhani. [2014]. Sistem Pendukung Keputusan.

[5] D. R. Sari, A. P. Windarto, D. Hartama, and S. Solikhun, "Sistem Pendukung Keputusan untuk Rekomendasi Kelulusan Sidang Skripsi Menggunakan Metode AHP-TOPSIS," Jurnal Teknologi dan Sistem Komputer, vol. 6, no. 1, pp. 1-6, Jan. 2018. doi: 10.14710/jtsiskom.6.1.2018.1-6, [Online].

[6] Marimin dan Nurul Maghfiroh. [2011]. Aplikasi teknik Pengambilan Keputusan Dalam Manajemen Rantai Pasok.

[7] Madcoms. [2015]. Mudah Menggunakan Internet untuk Pemula. 